\title{
The Legal Position of Informed Consent in the Doctor- Patient Relationship
}

\author{
Arina Ikasari Muhtadi ${ }^{1}$, Faisal Santiago ${ }^{2}$ \\ $\left\{\right.$ a_ikasari303@yahoo.com ${ }^{1}$, faisalsantiago@borobudur.ac.id $\left.{ }^{2}\right\}$ \\ Universitas Borobudur ${ }^{1,2}$
}

\begin{abstract}
Informed assent can be characterized as a patient's assertion or legitimately addressing him as an understanding with regards to a clinical activity plan presented by a specialist in the wake of getting adequate data, to have the option to settle on an arrangement or refusal. In pandemic era it is becoming more important to give patients all the information about how the medical procedures is going to perform and the possible complication that may occur as the unexpected outcomes. The marking of the composed assent structure is just an assertion of what has been recently concurred. The reason for the full clarification is for the patient to settle on his choice as per the patient's decision (informed choice), to further develop individuals' quality with regards to understanding the clinical activity. At the point when seen as far as the type of informed assent comprising of invalid assent (thought about given) and composed assent (expressed). The presence of informed assent is vital in the connection among specialist and patient, wherein informed assent is considered as the essential for making a clinical move against patient. In this paper will be depicted, clarified and examined the legitimate guidelines identified with the situation of informed assent in the connection among specialists and patients, particularly when the sudden results are happened unintendedly. The last point of this paper is that prior to making a clinical move, the patient has the option to get data about the clinical activity that should be performed on him as controlled in the Regulation of the Minister of Health (Permenkes) No. 290 of 2008 concerning Approval of Medical Action.
\end{abstract}

Keywords: informed consent; Approval of Medical Action; unexpected outcomes

\section{Introduction}

Lately, the issue of Human Rights (HAM) has become a major topic of discussion throughout the world, as well as in the medical world. The incessant flow of globalization in the field of information has also affected the people involved in the professional doctor-patient relationship in Indonesia.[7] Wellbeing is the main piece of human existence. Efficiency and an individual's exercises are affected by that individual's medical issue. Individuals can think well and can perform exercises ideally when they are sound. At the point when somebody's wellbeing is upset, they will view ways as back to being solid once more. One of them is by 
seeking therapy and seeking clinical treatment at the clinic accessible wellbeing administration offices, for example, wellbeing focuses, facilities, and clinics.[4]

Specialists and patients are two related lawful subjects in clinical law, both structure both a clinical and a lawful relationship. Clinical relations and the legitimate connection among specialist and patient is a relationship whose article is medical care overall and wellbeing administrations specifically. In do the connection among specialist and patient, the execution between the two is constantly managed with specific guidelines so that there is amicability in its execution. In the practice of the medical profession, there are often conflicts between doctors and patients, which cannot be resolved by ethical rules. In such circumstances, the rule of law can be applied.[7]

Clinical Law is essential for Health Law (Gezondheidsrecht) with an extension that main covers the clinical field, in particular specialists and individuals under their influence (attendants, birthing assistants) covering the fields of criminal, common and authoritative law. The rules that cover Medical Law are the right to medical services and the right to selfassurance.[10]

Patients as gatherings who need wellbeing administrations submit totally his medical services to a specialist as different gatherings. At the point when a patient goes to a specialist and tells his protest, and the specialist pays attention to the patient's grievances, then, at that point, there has been a commitment connection between the different sides. The appearance of the patient to the specialist's office, emergency clinic, or other wellbeing offices can be deciphered as an endeavor to make a proposal to a specialist, requesting help in defeating the protests he endured. The other way around, the specialist will give clinical benefits as a progression of activities that include: clinical analysis and treatment. This lawful relationship is here in after alluded to as an exchange, which in Civil Law is called an understanding, and in wellbeing administrations it is called a ,therapeutic arrangement" or ,therapeutic transaction"..[1,5,7,10] The legitimate connection among specialist and patient that is completed with a feeling of trust from the patient to the specialist is known as a restorative exchange.

In the law there are 2 (two) sorts of arrangements, namely:[5,7,10]

1. Inspanningverbintenis, to be specific a work understanding, implying that the two players guarantee or consented to put forth greatest attempts to acknowledge what was concurred.

2. Resultaatverbintenis, which is an agreement that will give the resultaat or a real results according to what was promised.

Restorative arrangements or helpful exchanges are remembered for inspanningverbintenis or a work understanding, in light of the fact that the specialist is probably not going to guarantee a fix to the patient, what specialists do is to give wellbeing administrations as a work to fix the patient.[4,5,7,10] In carrying out this effort, the doctor must do his fullest sincerity by mobilizing all the abilities and skills he has based on professional standards. In a therapeutic agreement, unlike the case ordinary agreement, there are some special conditions. In this condition, the patient is the one who asks assistance, so that his position is relatively weak compared to doctors. In order to reduce these weaknesses, another concept has been added to this agreement, known as informed consent, which is a patient's right to allow a medical action to be performed.[4,5,7] Recently, especially since the pandemic of SARS Cov2 , the existence of informed consent in medicine is increasingly becoming an issue of completeness, as a requirement made by a doctor before carrying out a medical action that has been planned. 


\section{Results and Discussion}

\subsection{Definition of Informed Consent}

The two primary angles in informed assent are data and assent, they have a wide assortment and is to some degree complex, including different components, to be specific specialist patient-family. In head, informed assent is a course of correspondence between the specialists and the patient in regards to the settlement on the clinical activity that the specialist will perform to the patient, (counting point by point clarification of clinical arrangement by the specialist), so an oral understanding was in reality enough. Marking the Informed Consent structure recorded as a hard copy is just an affirmation of what has been concurred already.[10]

The motivation behind a total clarification is that for the patient to settle on their own choices as per their own decisions (informed choices). In this way, the patient additionally has the privilege to deny the suggested clinical treatment. Patient also has the privilege to request the assessment of another specialist (second assessment).

Educated assent comprises regarding two words in particular "informed" which implies data or clarification and "assent" which comes from Latin language „Consentio" which implies understanding or giving authorization.[6,7,10] The term of informed assent in Bahasa Indonesia is made an interpretation of as agree to clinical activity, which comprises of two English syllables, specifically „Inform" which implies data and „consent" signifies understanding. So the significance of informed assent is an understanding given in the wake of getting the data. Consequently, educated assent can be characterized as the patient's assertion or any individual who honestly addressing him/her, which comprise of endorsement of the clinical activity plan put together by the specialist, subsequent to getting adequate data to consider endorsement or dissatisfaction. This endorsement of what the specialist will do should be managed with practically no component of intimidation.

Educated Consent as per Regulation regarding the Minister of Health (Permenkes) No. 585/Menkes/Per/IX/1989 : Approval of Medical Action is the assent given by the patient or his family dependent on the clarification with respect to the clinical activity to be performed on the patient.[1,9]

Jay Katz put forward the basic philosophy of informed consent, namely that in essence a decision to give treatment to a patient must occur collaboratively (cooperation) between doctor and patient, not merely a unilateral decision (doctor or patient). Thus, informed consent contains two main elements, namely voluntariness and understanding.[7] In a court about an instance of Informed Consent, it was expressed that ,the essential interest of informed assent is having the patient educated regarding every one of the material realities from which he can settle on a smart decision with respect to his course of treatment, whether or not he truth be told pick reasonably".[7]

The purpose of informed consent according to J. Guwandi are:[3]

1. To protects patients against all medical actions that are carried out without their knowledge

2. To provide legal protection to doctors against unexpected consequences, for example, to the unavoidable risk of treatment, even though the doctor has tried his best and acted very seriously careful and thorough.

Clinical benefits as one of the components of administration that assume a significant part in giving wellbeing administrations to patients. In that clinical benefit there are clinical work 
force as specialist co-ops (clinical suppliers) and patients as administration beneficiaries (clinical recipients). Each party has the right and commitments that should be regarded. In completing their calling, clinical faculty should be straightforward and hold the patient back from being hurt by it, other than that clinical staff should likewise realize matters identifying with informed assent as a fundamental or endorsement (grant) for clinical work force in giving clinical activity to the patient.

The shortfall of informed agree can prompt clinical misbehavior, particularly when there is mischief or mediation to the patient's body. Custom-based law in different nations express that the results of not having informed agree are identical to carelessness. Nonetheless, sometimes, the shortfall of informed agree identical to a deliberate demonstration, so the level of mistake of the specialist doing the activity is higher.

Physician malpractice actions that are considered to be on purpose are as follows:

1. The patient previously stated that he did not agree with the doctor's actions, but the doctor still perform the action

2. If the doctor intentionally misleads the risk and the consequences of the medical action

3. If the doctor intentionally hides the risks and consequences of a medical action

4. Informed consent is given to substantially different medical procedures with what the doctor did.

\subsection{Patient's Right to Information}

According to Szas and Hollender (1956), development of the doctor-patient relationship has underwent 3 stages:[10]

1. Activity-passivity / Paternalistic: doctors were always superior, patients only obey because doctors was believed to know more about the patient's health problems, and if the doctor was wrong the patient was not allowed to protest

2. Guidance - cooperation: the doctor guided the patient to make a decision, but the doctor still dominated

3. Mutual participation: is a model that we know now, there is equality between doctors and patients and the legal aspect has been able to align itself with the medical aspect (equality before the law). Doctors and patients work together to find solutions to the patient's health problems.

Since the sanctioning of the Regulation of the Minister of Health (Permenkes) No. 290 of 2008 with respect to Approval for Medical Action, the model of shared support is utilized and permitting the patient to reserve the option to get data about the clinical activity that will be done to him, prior to making any clinical move. This Permenkes additionally gives assurance to the freedoms of patients to decline clinical treatment. In this manner preceding any clinical activity the specialist should acquire the assent from the patient or the individual who has the privilege to give authorization for the activity which to be performed on the patient.

Patients' rights are actually human rights (HAM) that come from basic individuals rights in the health sector, (the right of self-determination).[10] Despite the fact that they are really a similar basic, yet the right to wellbeing administrations is frequently viewed as more fundamental. In the specialist patient relationship, the patient is in a moderately frail position, powerlessness of patients to shield their inclinations in medical care circumstances raises the need to question the freedoms of patients in managing wellbeing experts. The option to acquire data is the patient's most significant basic freedom, even in exceptional activities required informed assent (endorsement of clinical activity). 
In the connection between informed assent and clinical activities to be completed by specialists, one might say that educated assent is the primary part that upholds the clinical activity. Patients reserve the privilege to know everything identified with the condition of the infection, from the analysis, the clinical activity to be done, to the danger of the operation is being completed or not. Clinical data that patients reserve the option to know including the character of the specialist and the guidelines that apply at the medical clinic where he is being dealt with (for instance in regards to doctor's visit expense and installment techniques at the emergency clinic). Specialists may keeping clinical data, if doing as such will debilitate the patient's opposition.

Data that should be given to the patient or closest relative is managed in the Article 7 passage 3 which essentially incorporates:[7,10]

a. Analysis and methods for activity clinical;

b. The reason for the clinical activity taken;

c. Other elective activities, and the danger;

d. Dangers and intricacies that might happen;

e. Guess of activities taken;

f. Estimated financing

A portrayal of the patient's determination and condition of wellbeing might incorporate discoveries from the aftereffects of the clinical assessment to date; the conclusion of the infection (or on account of can't be set up, then, at that point, something like a functioning finding and differential analysis); sign or clinical state of the patient that requires clinical activity; and visualization (conceivable result of treatment) in case move is made and in case move isn't made.[10] This is directed in Article 8 section 1 of the Minister of Health Regulation No. 290 of 2008.

A clarification of the clinical activity taken is directed in Article 8 passage 2 of the Minister of Health Number 290 of 2008. They incorporate: [10]

a. the reason for the activity which can be as preventive, analytic, helpful, or rehabilitative purposes;

b. the methodology in completing the activity and what the patient will be capable during and after the technique, just as incidental effects or solace that might happen;

c. the elective activities, alongside the benefits and burdens contrasted with arranged activities, dangers and difficulties that might happen in every elective activity;

d. the extension of the activity what may be done to manage crises, because of dangers and complexities or other surprising conditions;

A clarification of the dangers and inconveniences of operations are largely dangers and entanglements that can happen following the clinical activity performed, aside from the danger and intricacies that have become normal information; the dangers and difficulties are exceptionally rare or extremely gentle effect; dangers and confusions that can't be recently envisioned (unforeseeable).[10] This is managed in Article 8 passage 3 Number 290 Year 2008 concerning Approval of Medical Action.

A clarification of the visualization incorporates anticipation of life and passing (advertisement vitam), forecast of capacity (promotion functionam), guess (conceivable result of treatment) about his recuperation (promotion sanationam). [10] This matter controlled in Article 8 section 4 of the Minister of Health Number 290 of 2008 concerning Approval of Actions Medical.

\subsection{Types of Informed Consent}


Clinical Action Consent (informed assent) brought forth a remedial understanding, which is an arrangement among specialist and patient that gives authoritation to specialists to do exercises to give wellbeing administrations to patients, in view of the mastery and abilities of the specialist. $[1,5,7,10]$ In the Preamble to the Indonesian Medical Code of Ethics appended to the Decree The Minister of Health of the Republic of Indonesia Number 434/Men.Kes/X/1983 concerning the Enforcement of the Code of Ethics Indonesian Medicine For Doctors in Indonesia, incorporates exchanges helpful as follows "What is implied by a restorative exchange is the connection between specialist with patient directed in a climate of shared trust (classification) and consistently overpowered by every one of the feelings, expectations and stresses of human instinct".

The lawful relationship in the restorative exchange emerges freedoms and commitments of each party, both for the patient and the specialist. An arrangement is supposed to be substantial in the event that it meets the prerequisites as specified in Article 1321 The Civil Code which peruses "There is no legitimate understanding if the understanding is given accidentally or acquired by pressure or misrepresentation". As per the article above, it tends to be reasoned that the juridical legitimacy of an understanding is controlled by the arrangement of the gatherings who tie themselves, with next to no slip-up, compulsion or extortion. This understanding is an arrangement that completed by the two players where the two players have understanding in a remedial exchange, as the patient's party consents to be treated by specialist, and the specialist consented to treat the patient. All together for this consent to be legitimate as per law, then, at that point, in this understanding the gatherings should know (there is no oversight) of the arrangement made, there ought to be no compulsion from one or the other party, and there might be no misrepresentation in it. Consequently, it is important to have informed assent or otherwise called Medical Action Approval.

There are 2 kinds of Medical Action Approval, namely :[1,7,10]

1. Suggested assent (thought about given): by and large inferred assent is given under typical conditions, implying that the specialist can catch the endorsement of the clinical activity from the signals given/performed by the patient. In like manner, in a crisis situation where the specialist requires prompt activity while the patient can't give assent and his family isn't there, the specialist can make the best clinical move as per the specialist.[1,4,10]

2. Expressed consent (expressed): can be expressed orally or in writing. In medical procedures that are invasive and contain risks, or if the results of the medical action are difficult to predict (doubtful), the doctor should obtain written approval, or what is generally known in hospitals as an operating license. [1,4,10]

When a medical action is taken, the possibility of things that are unexpected as the results of the action, such as complications from the action, disability and even death (at the operating table) may occur. Despite the fact that the patient has marked the educated assent however at that point if something destructive happens to the patient, doesn't imply that the specialist is liberated from his legitimate liability. All should be examined first, regardless of whether the activity: is as per the signs of the patient's ailment, whether it has been done by an equipped wellbeing laborers, whether it is as per standard working strategies and expert guidelines. Hence every assent given by the patient and family doesn't eliminate risk (legitimately, regardless of whether criminal or common) against specialists who are careless.[10]

Informed consent is a patient's right which is contained in Article 32 of Law Number 44 of 2009 concerning Hospitals which reads:[4]

1. To receive information which includes diagnosis and procedures for medical action, objectives of medical action, alternative actions, risks and complications that may occur, and prognosis of the actions taken as well as estimated costs of treatment; 
2. To give approval or to refuse the action which to be taken by the health worker for the disease he is suffering from.

Incapable conveyance of data can lead to different issues. Perhaps the specialist has given sufficient data to the patient. Nonetheless, since the patient doesn't comprehend the language utilized by the specialist, then, at that point, he might have question about the data. The patient marked the assent structure yet the patient concedes that the patient isn't educated and the patient fail to see what was endorsed. The specialist might feel that he has been given sufficient data to the patient, yet as indicated by the patient it might in any case insufficient, in light of the fact that the patient fail to really see what has been said by the specialist. Regularly the patient just hub his head and appeared to comprehend, with practically no inquiry posed, on the grounds that he may not realize what to ask to the specialist in any case. Specialists who accept the patient's gesture as an indication of comprehension would present the assent structure for clinical activity and the patient signs his mark. This regularly occurs on account of patient with least information.[4]

Therapeutic agreement is not always smooth sailing. Sometimes it can happen that one of the parties does not want to continue the transaction in this field of treatment. Generally, those who do not want to continue this transaction are from the patient or family. The cancellation of this agreement must be carried out properly, through a written cancellation in a Cancellation Sheet, which has legal force. The doctor may also cancel the agreement if the doctor faces a patient who is already uncooperative and is no longer sure about his treatment efforts, the doctor can give up and ask the patient to seek treatment from another doctor.[5,10]

\subsection{The Legal Position of Informed Consent}

For patients advantage, Medical Treatment Approval has been controlled in Article 45 of Law Number 29 of 2004 concerning Medical Practice. As expressed, each clinical or dental activity that will be completed by a specialist or dental specialist on a patient should acquire endorsement. The endorsement as alluded to is given after the patient has gotten a total clarification, essentially covering: determination and methods for clinical activity, the motivation behind the clinical activity taken, other elective activities and dangers, dangers and intricacies that might happen, and the visualization for the activity taken. It is expressed in it that any clinical or dental strategy that contains a high danger should be given with composed assent endorsed by the individual qualified for give the assent.[4]

Situating the connection between clinical work force and patients that has a lawful premise, can be begun with article 1313 of the Civil Code "An understanding is a demonstration by which at least one individuals tie themselves to at least one individuals".[1,5,10] In this manner the situation of patients and clinical work force in wellbeing administrations ought to be adjusted. On one hand, patients need clinical work force to conquer their medical issues, while then again clinical faculty need patients to acquire pay just as to rehearse the clinical information they have learned in instruction. Each party, for this situation clinical faculty who are in the situation of specialist organizations (clinical suppliers) and patients as administration beneficiaries (clinical collectors), have freedoms and commitments that should be regarded. In such a bond the issue of informed assent or this Medicine/Medical Action Approval may shows up. A patient or his family should be given the most clear data or clarification from the clinical staff about the clinical activities that will be done on the patient, so he can give endorsement or consent to the clinical work force. Hence the outcome will happen as "understanding" between the two gatherings. The two players concur and guarantee to accomplish something in the field of medication or wellbeing. Result 
in this arrangement, there will be an "commitment" between two gatherings, in particular the patient and the clinical staff.

In light of Article 1320 of the Civil Code, the commitment or an arrangement requires 4 after conditions to be satisfied:[5,10]

1. Agreement (toesteming) on those who bind themselves, who are the patient and the doctor

2. The capacity to make an agreement, both patient and doctor are capable of making agreement

3. Something certain, in this case is a disease or condition that needs to be treated by a doctor as the object of agreement (onderwerp der overeenskomst)

4. Something that with legal cause (geoorloofde oorzaak), that the agreement is lawful and does not violate the law, the good moral nor public order

It is not true that medical personnel is thought to rarely ask for patient's consent from for a series of medical effort, except for the case of surgery and actions that have a high medical risk only. Medical personnel will always give clear explanation and never forced the patient to agree with the medical plan, whether the patient is paying the service with his own money, or with private insurance, or public / government insurance. However, Guwandi stated that it is impossible for doctors to explain all the risks that may arise in a surgery, so only certain elements related to the case that need to be explained. The elements of risk include:[2,7]

a. The nature of the risk

b. The level of seriousness (magnitude) of the risk

c. The probability of the risk

d. When or the period of time the risk may arise, if it will arise.

Practically speaking, apparently the connection between clinical faculty and patients isn't similarly adjusted, in light of the fact that clinical staff have a predominant position while patients are generally inactively pausing and appearing to be surrendered to what the clinical work force will do against him.

Article 52 letters an and d of The Medical Practice Act clarifies that patients, in getting administrations in clinical practice, has the option to get a total clarification of clinical therapy as alluded to in article 45 section (3) and what's more the patient has the privilege to decline clinical therapy. In this manner, educated assent or Consent regarding Medicine/Medical Actions are an absolute necessity for clinical work force in arranging therapy for the patient. Guideline of the Minister of Health of the Republic of Indonesia Number 290/Menkes/Per/III/2008 in regards to endorsement of clinical activities are expressed in Articles 1, 2, and 3, to be specific:

Article 1: Assent for clinical activity is the assent given by the patient or nearest family in the wake of getting a total clarification of the activity medication or dentistry to be performed on the patient. The nearest family are spouse or wife, organic dad or mother, natural kids, kin or gatekeepers.

Article 2:

1. All medical actions that will be carried out on patients must receive agreement

2. The approval as referred to in paragraph 1 can be given in writing or verbally

3. The approval as referred to in paragraph 1 is given after the patient has received the necessary explanation regarding the need for medical action to be carried out. Article 3:

1. Every medical procedure that contains a high risk must obtain a written agreement signed by the person entitled to give the consent.

2. Medical actions that are not included in the provisions as referred to in paragraph 1 may be given with verbal consent. 
3. The written approval as referred to in paragraph 1 is made in the form of a statement contained in a special form made for that purpose

Informed Consent rules whenever carried out appropriately among specialist and patient will be similarly secured by law. However, in case there is a demonstration outside the guidelines that has been made is surely viewed as an infringement of the law. Infringement of Informed Consent has been controlled in article 19 of the Minister of Health Number 290 of 2008 concerning Approval of Medical Actions, proclaimed against specialists who make a move without Informed Consent, might be liable to sanctions as verbal admonitions, composed alerts, up to the denial of the letter of Practice Permit.

Informed consent in Indonesia is also regulated in the following regulations:

1. Law of the Republic of Indonesia Number 23 of 1992 concerning Health in conjunction with Law Number 36 Year 2009 concerning Health.[1]

2. Indonesian Hospital Code of Ethics (KODERSI).

3. Regulation of the Minister of Health of the Republic of Indonesia Number 585/Men.Kes/Per/IX/1989 concerning Approval Medical Action.[1,9]

4. Regulation of the Minister of Health of the Republic of Indonesia Number 1419/Men.Kes/Per/X/2005 regarding the Implementation of Medical Practice.[8]

5. Decree of PB IDI (Indonesian Doctors Association) No. 319/PB/A4/88.

\section{Conclusion and Suggestion}

\subsection{Conclussion}

Informed assent can be characterized as a patient assertion or any individual who address him legitimately, whose substance are as endorsement of the proposed clinical activity plan by a specialist subsequent to getting adequate data to have the option to settle on an understanding or dismissal. Before any clinical activity is played out, the patient has the option to get data about the clinical activity that will be done to him. As specified in the Regulation of the Minister of Health (Permenkes) No. 290 years 2008 Regarding Medical Action Approval, whenever saw from the part of its structure, then, at that point, educated Consent comprises regarding imflied assent (thought about given) and communicated assent (expressed). The presence of informed assent is vital in the specialist patient relationship where informed assent is the fundamental or establishment for specialists to make a move for clinical consideration to the patients.

\subsection{Suggestion}

The knowledge of informed consent for each patient who will be given any medical treatment is very important. This is because to give the clear legal position related to his rights and obligations as a patient. In pandemic era it is becoming more important to give patients all the information about how the medical procedures is going to perform and the possible complication that may occur as the unexpected outcomes.

The doctor who will perform a medical action should also know the limits of the action of medical treatment to be taken. For a doctor, informed consent is not just information on paper that has been signed by a patient, but also as an information that provides a limit for a doctor in taking medical action. 
The position of informed consent is very clear in the eyes of the law, therefore with providing socialization on the importance of informed consent will provide awareness for patients and doctors in a legal relationship for both parties.

\section{References}

[1] Amir, Amri. (1997). Bunga Rampai Hukum Kesehatan. Jakarta: Widya Medika.

[2] Biben, Achmad. (2005). Alternatif : Bentuk Informed Consent Dalam Praktik Dan Penelitian Kedokteran. Bandung: FK UNPAD.

[3] Guwandi, J. (2005). Rahasia Medis. Jakarta: Penerbit Fakultas Kedokteran UI.

[4] Irfan. (2008). Kedudukan Informed Consent Dalam Hubungan Dokter Dan Pasien. Jurnal Ilmu Hukum Fakultas Hukum Umsu. Volume 3 Nomor 2.

[5] Jusuf Hanafiah, M., \& Amir, Amri. (2016). Etika Kedokteran dan Hukum Kesehatan. Jakarta: Penerbit Buku Kedokteran.

[6] Konsil Kedokteran Indonesia. (2006). Komunikasi Efektik Dokter-Pasien. Jakarta: KKI.

[7] M, Chrisdiono., \& Achadiat. (2006). Dinamika Etika dan Hukum Kedokteran Dalam Tantangan Zaman. Jakarta: Penerbit Buku Kedokteran.

[8] Peraturan Menteri Kesehatan Republik Indonesia Nomor 1419/Menkes/Per/X/2005 Tentang Penyelenggaraan Praktik Dokter dan Dokter Gigi.

[9] Peraturan Menteri Kesehatan RI Nomor 585/Men.Kes/Per/IX/1989 tentang Persetujuan Tindakan Medis.

[10] Ratman, Desriza. (2018). Aspek Hukum Informed Consent dan Rekam Medis dalam Transaksi Terapeutik. Cetakan ke-2. Bandung: Keni Media. 